\title{
Ultrafine particles and nitrogen oxides generated by gas and electric cooking
}

\author{
M Dennekamp, S Howarth, C A J Dick, J W Cherrie, K Donaldson, A Seaton
}

\begin{abstract}
Objectives-To measure the concentrations of particles less than $100 \mathrm{~nm}$ diameter and of oxides of nitrogen generated by cooking with gas and electricity, to comment on possible hazards to health in poorly ventilated kitchens.

Methods-Experiments with gas and electric rings, grills, and ovens were used to compare different cooking procedures. Nitrogen oxides $\left(\mathrm{NO}_{\mathrm{x}}\right.$ ) were measured by a chemiluminescent ML9841A NO analyser. A TSI 3934 scanning mobility particle sizer was used to measure average number concentration and size distribution of aerosols in the size range 10-500 nm.
\end{abstract}

Results-High concentrations of particles are generated by gas combustion, by frying, and by cooking of fatty foods. Electric rings and grills may also generate particles from their surfaces. In experiments where gas burning was the most important source of particles, most particles were in the size range $15-40 \mathrm{~nm}$. When bacon was fried on the gas or electric rings the particles were of larger diameter, in the size range 50-100 $\mathrm{nm}$. The smaller particles generated during experiments grew in size with time because of coagulation. Substantial concentrations of $\mathrm{NO}_{\mathrm{x}}$ were generated during cooking on gas; four rings for 15 minutes produced 5 minute peaks of about $1000 \mathrm{ppb}$ nitrogen dioxide and about $2000 \mathrm{ppb}$ nitric oxide. Conclusions-Cooking in a poorly ventilated kitchen may give rise to potentially toxic concentrations of numbers of particles. Very high concentrations of oxides of nitrogen may also be generated by gas cooking, and with no extraction and poor ventilation, may reach concentrations at which adverse health effects may be expected. Although respiratory effects of exposure to $\mathrm{NO}_{\mathrm{x}}$ might be anticipated, recent epidemiology suggests that cardiac effects cannot be excluded, and further investigation of this is desirable. (Occup Environ Med 2001;58:511-516)

Keywords: cooking fuels; nitrogen oxides, ultrafine particles

Many studies have now shown associations between the airborne concentrations of particles and cardiorespiratory ill health. ${ }^{1-4}$ Most have focused on the mass of particulate matter less than either 10 or $2.5 \mu \mathrm{m}$ in aerodynamic diameter $\left(\mathrm{PM}_{10}\right.$ and $\left.\mathrm{PM}_{2.5}\right)$. It has been hypothesised that these effects may be due to the $\mathrm{nm}$ sized particles (ultrafine particles (UFPs)) comprising the largest number of particles, rather than the mass which is principally determined by larger, greater than $1 \mu \mathrm{m}$, sized particles. ${ }^{5}$ This implies that particle numbers could be a better metric than particle mass for predicting health effects and for control purposes. This ultrafine hypothesis was based on animal studies that showed nm sized particles to be toxic, whereas larger particles of the same material were not. ${ }^{6-8}$ It was recognised that most studies relating health effects to particulate pollution are based on $\mathrm{PM}_{10}$ measured in urban air, where UFPs generated by combustion are an important component. Relatively few studies have so far tested the ultrafine hypothesis, although there is toxicological evidence in support of the earlier studies showing that both small size and adsorbed transition metals may contribute to toxicity. ${ }^{9}$ Epidemiologically, to date studies of associations between the number and mass concentrations of particles in the outdoor air and health effects have given conflicting results, suggesting that number of UFPs may be more relevant to cardiac effects. ${ }^{10-12}$

As well as this there is evidence of associations between exposure to nitrogen dioxide $\left(\mathrm{NO}_{2}\right)$ and adverse health effects. At high concentrations $\mathrm{NO}_{2}$ may increase sensitivity to allergens in asthmatic people, ${ }^{13}$ whereas at ambient concentrations it also has been associated with exacerbations of asthma and increased death rates. ${ }^{14-16}$ Most recently, it has been associated with episodes of cardiac arrhythmia in subjects with implanted defibrillators. ${ }^{17}$ This evidence is not wholly consistent, and as there are close correlations between $\mathrm{NO}_{2}$ in the general environment and other pollutants derived from traffic, a question remains as to whether these low level associations may be due to confounding.

Most people spend at least $90 \%$ of their time indoors and the question therefore arises as to how relevant air pollution generated indoors is to adverse health effects. The most important indoor activities generating particles are smoking and cooking. ${ }^{18}$ Several studies have investigated relations between cooking and respiratory symptoms, and some have shown that children who live in houses where gas is used have more respiratory symptoms than children who live in houses where other cooking fuels are used. ${ }^{19-22}$ Jarvis et $a l^{23}$ also showed an association between gas cooking and aggravation of asthmatic symptoms. These effects have generally been attributed to increases in concentrations of $\mathrm{NO}_{2} \cdot{ }^{20}$ However, Garrett et 
$a l^{25}$ concluded that exposure to gas cooking was an important risk factor for respiratory symptoms even after adjusting for concentrations of $\mathrm{NO}_{2}$, suggesting an additional hazard associated with the use of gas stoves. Recently we reported in this fournal that $\mathrm{PM}_{10}$ generated by gas cooking has the potential to cause proinflammatory effects in lung cells. ${ }^{26}$

In this paper, we present the results of studies of the generation of UFPs and nitrogen oxides $\left(\mathrm{NO}_{\mathrm{x}}\right)$ during different cooking procedures, and discuss the possibility that such pollutants may contribute to the health effects found in people who use gas for cooking.

\section{Methods}

LABORATORY

The study was conducted in a laboratory (volume $70 \mathrm{~m}^{3}$ and internal surface area about 130 $\mathrm{m}^{2}$ ) in Aberdeen. No mechanical ventilation was used during the studies and the windows were closed during all measurements. The only potential sources of particles present in the laboratory were a gas and an electric cooker, both with four rings, an eye level grill, and an oven. The rings of the electric cooker were closed metal plates.

NITROGEN OXIDES

The concentrations of nitric oxide (NO) and $\mathrm{NO}_{\mathrm{x}}\left(\mathrm{NO}+\mathrm{NO}_{2}\right)$ were measured with a chemiluminescent ML9841A $\mathrm{NO}_{\mathrm{x}}$ analyser. The $\mathrm{NO}_{2}$ was obtained by subtracting $\mathrm{NO}$ from $\mathrm{NO}_{\mathrm{x}}$. Concentrations of $\mathrm{NO}_{\mathrm{x}}$ were measured at face level in front of the cookers. The lower detection limit of the monitor was $0.5 \mathrm{ppb}$. The instrument was calibrated with certified gas probes for $\mathrm{NO}_{\mathrm{x}}$. Data were stored every $5 \mathrm{~min}$ utes in an internal memory, downloaded, and exported into Microsoft Excel.

\section{ULTRAFINE PARTICLES}

A TSI 3934 scanning mobility particle sizer was used to measure average concentrations of numbers and size distribution of aerosols in the size range $10-500 \mathrm{~nm}$. Particles were electrically charged to a known charge distribution with a bipolar charger in a Model 3071A electrostatic classifier. The particles were then classified according to their ability to traverse an electric field, and counted with a Model 3022A condensation particle counter. Sampling was through straight copper tubing, a

Table 1 The cooking experiments

\begin{tabular}{lrll}
\hline Experiment & Time (minutes) & Power & Details \\
\hline Rings: & & & \\
1 Ring & 15 & Full power & \\
4 Rings & 15 & Full power & \\
Boil water & 15 & Full power & Water 11 \\
Stir fry & 5 & Full power & Vegetables $500 \mathrm{~g}$ \\
& & & Vegetable oil $15 \mathrm{ml}$ \\
Fry bacon & 7 & Full power & Bacon 4 rashers \\
Oven: & & & Vegetable oil $15 \mathrm{ml}$ \\
Bake cake & 40 & $180^{\circ} \mathrm{C}$ & \\
Roast meat & 75 & $180^{\circ} \mathrm{C}$ & Sponge cake \\
Bake potatoes & 75 & $180^{\circ} \mathrm{C}$ & Turkey joint $500 \mathrm{~g}$ \\
Grill: & & & Potatoes 2, total $500 \mathrm{~g}$ \\
Grill only & 15 & Full power & \\
Toast & 5 & Full power & Bread 2 slices \\
Grill bacon & 10 & Full power & Bacon 4 rashers \\
\hline
\end{tabular}

method that we had shown previously to result in minimal loss of particles. ${ }^{12}$ The system is automated with a personal computer and data were downloaded and exported in a Microsoft Excel spreadsheet format. Samples were taken in two 2.5 minute scans and the scanning mobility particle sizer system calculated $5 \mathrm{e}$ minute averaging periods, which were used in processing the data. The scanning mobility particle sizer system was calibrated by Bristol Industrial Research Associates. All test and calibration data have been obtained with standards, the accuracies of which are traceable to a nationally recognised standards laboratory, or have been verified by instrumentation, the accuracy of which is traceable to a nationally recognised standards laboratory, or is derived from accepted values of physical contents. Particle number concentrations were measured at the same place as the $\mathrm{NO}_{\mathrm{x}}$, at face level in front of the cookers. The UFP concentration in this paper is presented as the number of particles between $10 \mathrm{~nm}$ and $100 \mathrm{~nm}$. The particle numbers in the size range $10-500 \mathrm{~nm}$ (which are divided in 53 size ranges by the scanning mobility particle sizer system) were used to assess the ranges of the particle sizes.

\section{COOKING EXPERIMENTS}

All cooking experiments were carried out between March and December 1999. The experiments with the gas and the electric cooker were all performed the same way, comparing effects of the two cooking fuels. For every cooking experiment (use of rings, oven, and grill) both fatty (bacon) and low fat (bread, potato, or vegetable) foods were cooked. The different methods carried out are presented in table 1 .

LOSSES OF OXIDES OF NITROGEN AND PARTICLES FROM THE ROOM AIR

The loss of $\mathrm{NO}_{\mathrm{x}}$ and UFPs was estimated from the decay curve for each pollutant at the end of a period of cooking and presented as the time in minutes it took for the concentration to fall by $50 \%$. Loss rates were only estimated if there was a clear rise in the concentration of pollutant during the cooking experiment together with a decay curve that did not show any irregular pattern. For $\mathrm{NO}_{\mathrm{x}}$ the loss was from a combination of air exchange and adsorption onto surfaces. ${ }^{27}$ Loss of UFPs was assumed to be due to exchange with the outdoor air, deposition on room surfaces, and coagulation. Information on the deposition velocity for UFPs was not available, but it was assumed that this makes a relatively small contribution. The loss of concentration of particle numbers from coagulation is dependent on the square of the concentration, which means that it will be relatively more important at the end of a period of cooking when the UFP concentration is highest. ${ }^{28}$

STATISTICAL ANALYSES

The results of the concentrations of particle numbers and $\mathrm{NO}_{x}$ during cooking are presented as the maximum 5 minute concentration that occurred during the cooking method 
above the baseline concentration. Baseline concentrations were calculated by taking the average concentration of eight measurements; four just before the start of the cooking experiment and four after the experiment when the rise in particles or $\mathrm{NO}_{\mathrm{x}}$ had gone back to a steady level. For comparison between concentrations of particle numbers and $\mathrm{NO}_{\mathrm{x}}$ generated during different cooking methods, the non-parametric Mann-Whitney test was used. A p value 0.05 or less was taken as significant.

\section{Results}

COOKING EXPERIMENTS

Numbers of UFPs and concentrations of $N O_{X}$

The peak concentrations of number of UFPs for the different cooking methods are presented in table 2 . In general, cooking with gas generated more particles than did electricity. Table 3 presents the $\mathrm{NO}_{\mathrm{x}}$ concentrations generated during gas cooking. When the electric cooker was used, there was no rise in $\mathrm{NO}_{\mathrm{x}}$. When gas rings were fully turned on, concentrations of both number of UFPs and $\mathrm{NO}_{\mathrm{x}}$ rose rapidly (fig 1 ). Four gas rings burning resulted in a rapid rise in UFPs to on average $150000 \mathrm{UFP} / \mathrm{cm}^{3}$ and a rise in $\mathrm{NO}_{2}$ and $\mathrm{NO}$ respectively on average to about $1000 \mathrm{ppb}$ and about $2000 \mathrm{ppb}$. The gas grill alone did not generate detectable concentrations of $\mathrm{NO}$ or $\mathrm{NO}_{2}$. One electric ring without anything on it resulted in three of five occasions in a rise in numbers of UFPs; however a pot with water on the ring never resulted in a rise in numbers of UFPs. Four electric rings on full power did result on all occasions in a rise in UFPs to about $110000 \mathrm{UFPs} / \mathrm{cm}^{3}$.

Frying bacon on the gas rings caused the highest peak concentration of numbers of UFPs, $590000 \mathrm{UFP} / \mathrm{cm}^{3}$. The peak concentration of

Table 2 The maximum 5 minute UFP numbers above baseline, and the particle size at peak concentration for each cooking method

\begin{tabular}{|c|c|c|c|c|}
\hline Experiment & Cooking fuel & $n^{*}$ & $\begin{array}{l}\text { Peak concentration above } \\
\text { baseline of } U F P / \mathrm{cm}^{3} \\
\text { mean }(S D) \times 10^{4}\end{array}$ & $\begin{array}{l}\text { Particle size (nm) at } \\
\text { peak concentration } \\
\text { mean (SD) }\end{array}$ \\
\hline \multicolumn{5}{|l|}{ Rings: } \\
\hline \multirow[t]{2}{*}{1 Ring } & Gas & 4 & $2.6(1.2)$ & $16(13)$ \\
\hline & Electric & 5 & $9.4(7.2) \dagger$ & $32(14) \dagger$ \\
\hline \multirow[t]{2}{*}{4 Rings } & Gas & 6 & $14.6(8.3)$ & $26(12)$ \\
\hline & Electric & 6 & $11.1(10.4)$ & $37(13)$ \\
\hline \multirow[t]{2}{*}{ Boil water } & Gas & 4 & $13.3(8.1)$ & $17(5)$ \\
\hline & Electric & 5 & - & - \\
\hline \multirow[t]{2}{*}{ Stir fry } & Gas & 5 & $13.7(12.6)$ & $41(8)$ \\
\hline & Electric & 3 & $1.1(0.2)$ & $22(2)$ \\
\hline \multirow[t]{2}{*}{ Fry bacon } & Gas & 6 & $59.0(14.7)$ & $69(10)$ \\
\hline & Electric & 5 & $15.9(5.0)$ & $72(20)$ \\
\hline \multicolumn{5}{|l|}{ Oven: } \\
\hline \multirow[t]{2}{*}{ Bake cake } & Gas & 2 & $9.8(0.9)$ & $34(1)$ \\
\hline & Electric & 2 & $3.0(0.1)$ & $38(6)$ \\
\hline \multirow[t]{2}{*}{ Roast meat } & Gas & 3 & $12.4(2.0)$ & $31(7)$ \\
\hline & Electric & 2 & $2.4(1.4)$ & -5 \\
\hline \multirow[t]{2}{*}{ Bake potatoes } & Gas & 3 & $12.5(5.5)$ & $39(2)$ \\
\hline & Electric & 2 & $1.6(1.2)$ & $46(4)$ \\
\hline \multicolumn{5}{|l|}{ Grill: } \\
\hline \multirow[t]{2}{*}{ Grill only } & Gas & 5 & $10.3(12.4)$ & $24(6)$ \\
\hline & Electric & 5 & $7.7(11.1)$ & $20(7)$ \\
\hline \multirow[t]{2}{*}{ Toast } & Gas & 5 & $13.8(13.9)$ & $25(6)$ \\
\hline & Electric & 4 & $13.4(4.0)$ & $27(5)$ \\
\hline \multirow[t]{2}{*}{ Grill bacon } & Gas & 4 & $41.3(10.8)$ & $39(7)$ \\
\hline & Electric & 3 & $53.0(3.8)$ & $53(9)$ \\
\hline
\end{tabular}

${ }^{\star}$ Fewer replicated oven experiments were able to be carried out owing to a temporary failure of the SMPS system.

†Based on three of the five experiments, as two of the experiments did not show a rise in particle numbers.

$\ddagger$ No change in concentration due to the cooking method.

$§$ Not possible to give one size (multiple peaks).
Table 3 The maximum 5 minute concentrations of nitric oxide (NO) and nitrogen dioxide $\left(\mathrm{NO}_{2}\right)$ above baseline for each cooking method

\begin{tabular}{llll}
\hline & \multicolumn{3}{c}{$\begin{array}{l}\text { Peak concentration above } \\
\text { baseline }(p p b) \\
\text { mean }(S D)\end{array}$} \\
\cline { 3 - 4 } Experiment & $n$ & $\mathrm{NO}_{2}$ & $\mathrm{NO}$ \\
\hline Rings: & & $437(219)$ & $572(139)$ \\
1 Ring & 4 & $310(52)$ & $819(30)$ \\
2 Rings & 2 & $584(13)$ & $1378(172)$ \\
3 Rings & 3 & $996(139)$ & $2060(293)$ \\
4 Rings & 6 & $184(52)$ & $402(150)$ \\
Boil water & 4 & $92(5)$ & $114(15)$ \\
Stir fry & 5 & $104(19)$ & $120(7)$ \\
$\quad$ Fry bacon & 6 & $230(13)$ & $627(44)$ \\
Oven: & & $296(52)$ & $892(174)$ \\
$\quad$ Bake cake & 2 & $373(70)$ & $1047(164)$ \\
$\quad$ Roast meat & 3 & & \\
Bake potatoes & 3 &
\end{tabular}

UFPs generated by frying bacon on gas was significantly higher than that by frying vegetables on gas $(p=0.006)$. Frying bacon on gas also resulted in a significantly higher peak concentration of UFPs than frying bacon on an electric ring $(\mathrm{p}=0.006)$.

Use of the gas oven generated more UFPs than use of the electric oven. The gas oven also generated high peaks of $\mathrm{NO}_{\mathrm{x}}$. For example, cooking potatoes for 75 minutes resulted in $\mathrm{NO}_{2}$ peaks of about $370 \mathrm{ppb}$ and $\mathrm{NO}$ peaks of about 1000 (table 3). There was a progressive rise in $\mathrm{NO}_{2}$ and $\mathrm{NO}$ until the oven was turned off (fig 2) and a steady concentration was not reached. The particle concentration did, however, reach a plateau at about 120000 $\mathrm{UFP} / \mathrm{cm}^{3}$.

To investigate whether the rises in UFPs and $\mathrm{NO}_{x}$ in these short term experiments were caused mainly by ignition (which was electronic) or would continue with continued combustion, four gas rings were kept on full power for 2 hours. After an initial rapid rise in particles, the concentration declined. However, particles were still being generated after this initial rise while the gas was still burning, as a much steeper fall in concentration of particle numbers occurred after the rings were turned off (fig 3). The $\mathrm{NO}_{\mathrm{x}}$ reached steady concentrations after the rings had been on for 75 minutes, with $\mathrm{NO}_{2}$ concentrations of $2200 \mathrm{ppb}$ and NO concentrations of $5800 \mathrm{ppb}$. In our experiments the $\mathrm{NO}$ concentrations were always higher than those of $\mathrm{NO}_{2}$ during the use of the gas rings and oven. This lasted for at least 2 hours after the cooking experiments were finished (fig 3).

LOSSES OF OXIDES OF NITROGEN AND PARTICLES FROM THE ROOM AIR

Losses of $\mathrm{NO}_{\mathrm{x}}$ and UFPs were measured for 23 experiments, where both showed a clear rise due to the experiments. The measured mean (SD) $50 \%$ loss rate for $\mathrm{NO}_{\mathrm{x}}$ was 67 (27) minutes. The mean (SD) $50 \%$ loss rate for UFPs was twice as fast, at 30 (10) minutes. The reason for the higher loss rate for UFPs is likely to be coagulation of the particles. ${ }^{28}$

PARTICLE SIZES

The peak particle sizes described below are the mode of the UFP number distribution 


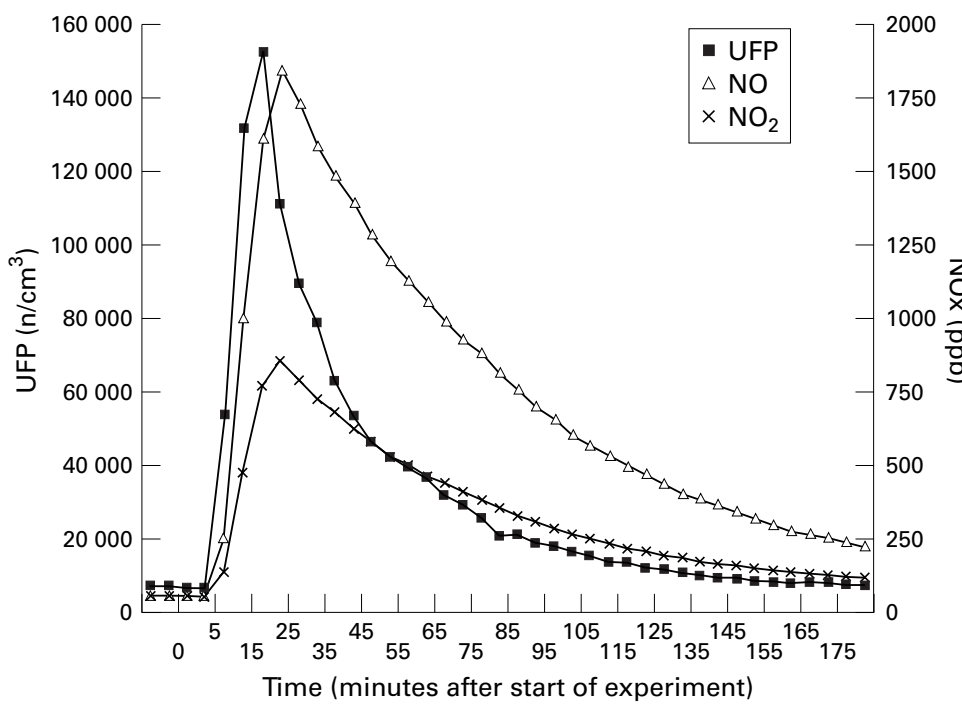

Figure 1 Concentrations of numbers of UFPs, nitric oxide (NO), and nitrogen dioxide $\left(\mathrm{NO}_{2}\right)$ when four gas rings were turned on full power for 15 minutes.

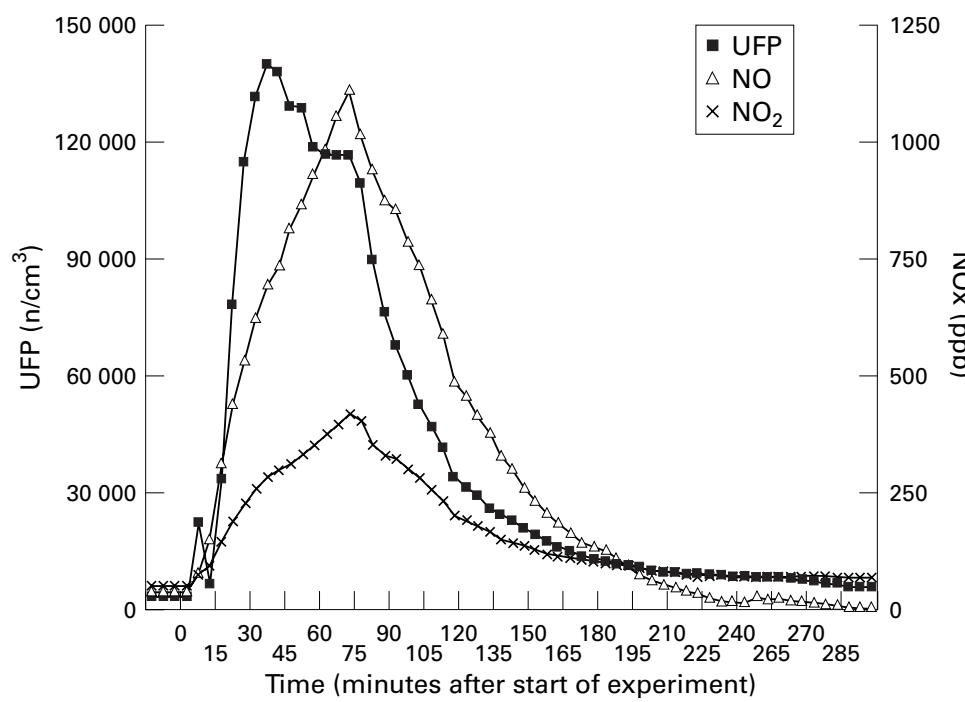

Figure 2 Concentrations of numbers of UFPs, nitric oxide (NO), and nitrogen dioxide $\left(\mathrm{NO}_{2}\right)$ when potatoes were cooked in the gas oven for 75 minutes.

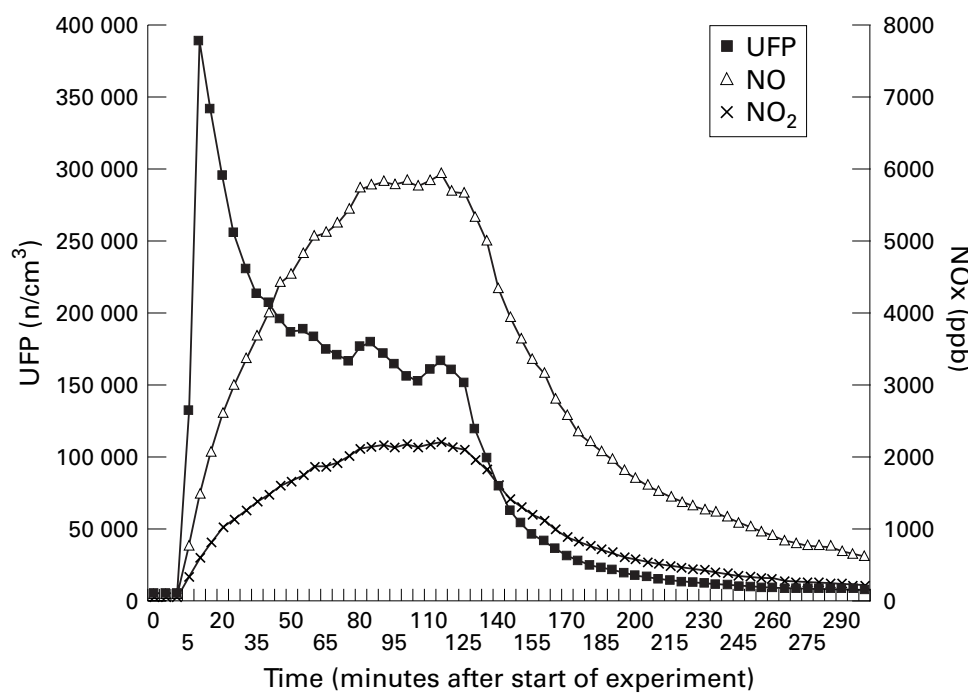

Figure 3 Concentrations of numbers of UFPs, nitric oxide (NO), and nitrogen dioxide $\left(\mathrm{NO}_{2}\right)$ while four gas rings were turned on full power for 2 hours. measured during the experiments (table 2). Particles produced by the gas rings alone and by boiling water on gas had a peak diameter in the range $15-40 \mathrm{~nm}$. The peak was in the same size range for the particles that were produced when the gas grill alone was turned on and when electric rings were turned on without a $z$ pan. When bacon was fried on the gas or electric rings the particles were larger, most particles being in the size range $50-100 \mathrm{~nm}$. ㄷ Immediately after the gas rings were turned on, the highest numbers of particles were in the very fine size range, but thereafter the particles grew in size with time. Figure 4 shows the size range of particles generated while four gas rings were on for 2 hours. Five, 15, and 30 minutes after the rings were turned on, the peak concentration was respectively at 15,30 , and $40 \mathrm{~nm}$ diameter. Thus, while the gas rings were burning, the particles grew up to a peak of about $50-70 \mathrm{~nm}$. The only situation in which particles did not grow with time was in some of the bacon frying experiments, when the initial particle size was already relatively large, up to $80 \mathrm{~nm}$. The most plausible explanation for the findings is coagulation of the very small particles into larger agglomerates.

\section{Discussion}

Many epidemiological studies have now shown relations between exposure to outdoor particulate air pollution and ill health. Similar relations have also been shown with $\mathrm{NO}_{2}$. In $\frac{x}{\sigma}$ both cases these associations seem to be present even at what are, in conventional toxicological terms, very low concentrations. Moreover, they occur despite the fact that most people spend at least $90 \%$ of their time indoors. These findings raise two important issues. Firstly, if the associations are causative, other sources of particles and $\mathrm{NO}_{\mathrm{x}}$ would be expected to influence the health of exposed people. We therefore asked ourselves what concentrations might arise in kitchens relative to those outside. Secondly, if total exposure to the toxic substances is an important determinant of effects, a proportion of this is likely to occur indoors. Further refinement of epidemiological studies is likely to require modelling of individual exposures, and it will therefore be necessary to know the contribution to these of indoor exposures. The present study was therefore also planned as a first step towards such modelling and also as part of a study to determine whether particles and gases generated indoors have the same toxicity as those outdoors.

We found that many UFPs are produced not only by gas combustion but also from heating electric plates and grills. Cooking with electricity or gas has the potential to add to particle numbers, mainly through frying and grilling of fatty foods and through the use of fats for frying. Particles generated by gas combustion are smaller in size than particles generated by cooking fatty food. Two recent studies have also investigated concentrations of particle numbers indoors. Wallace ${ }^{29}$ identified the gas oven, gas burners, and the electric toaster as being the most important sources of UFPs. Abt 


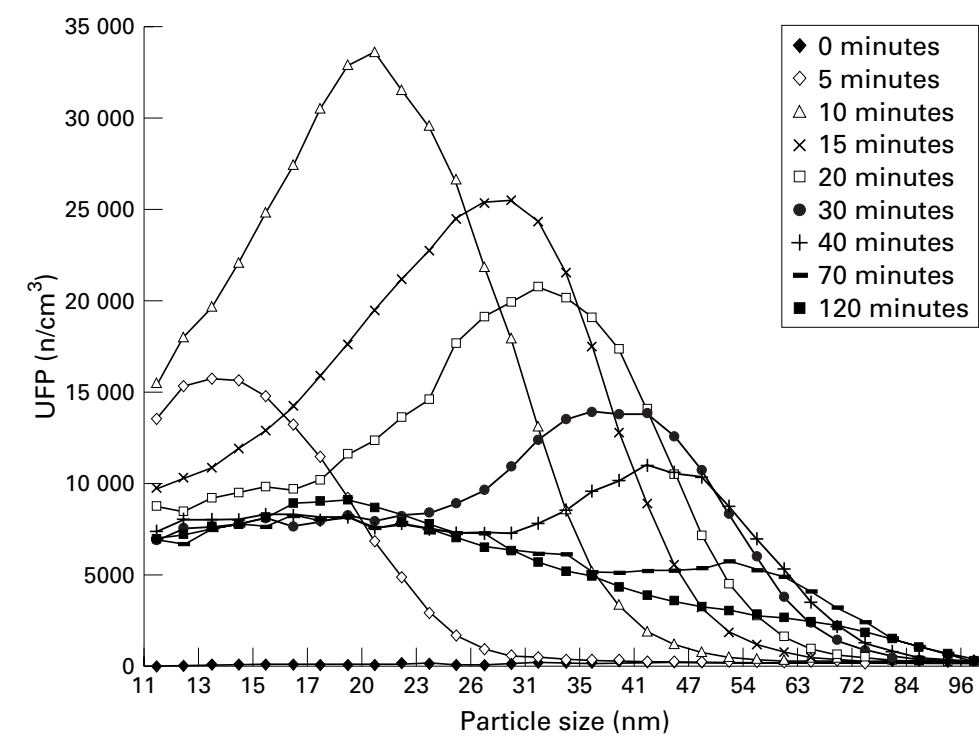

Figure 4 Distribution of particle size at different times while four gas rings were turned on full power for 2 hours. height in front of the cookers, and concentrations measured here are likely to overestimate the exposures of a cook. Moreover, we did not actively ventilate the laboratory during the experiments and there was no extractor fan present. However, when frying bacon and stir frying vegetables, the concentrations measured during the cooking experiments should be close to the actual exposure of a person cooking.

The current United Kingdom standard for ambient air $\mathrm{NO}_{2}$ is based primarily on experimental exposure studies in humans, which have shown subtle effects on inflammatory markers and increased susceptibility to allergens at concentrations around $200 \mathrm{ppb}^{32}$ Epidemiological studies have shown effects on populations at lower concentrations, and a recent panel study has suggested that vulnerable people with cardiac disease may have effects at ambient concentrations below 40 ppb. ${ }^{17}$ If $\mathrm{NO}_{2}$, or conceivably $\mathrm{NO}$, is responsible for these effects, a kitchen where concentrations of $\mathrm{NO}_{\mathrm{x}}$ can be relatively high might be an important source of exposure. Concentrations of $\mathrm{NO}_{2}$ in homes have been investigated in several studies and internal sources tend to be the dominant contributor to personal exposure, the most important being environmental tobacco smoke and gas cooking. ${ }^{33-38}$ In this study we have shown that using the gas rings and oven generated substantial amounts of $\mathrm{NO}_{2}$, certainly of a concentration that can cause ill effects in humans, for example by increasing susceptibility to allergens and causing airway inflammation. ${ }^{39}$ During gas cooking background concentrations increase dramatically and short term indoor concentrations are higher than are reached outdoors. In Aberdeen, during 1999, the highest hourly outside $\mathrm{NO}_{2}$ and $\mathrm{NO}$ concentrations were respectively $63 \mathrm{ppb}$ and $357 \mathrm{ppb}$, and such concentrations were only reached rarely. Concentrations of $\mathrm{NO}_{2}$ are monitored at 83 national network sites across the United Kingdom and in 1998 the highest 99.8 th percentage value of hourly concentrations was $140 \mathrm{ppb}$ at a kerbside site in Glasgow. We found hourly $\mathrm{NO}_{2}$ concentrations of more than $300 \mathrm{ppb}$ with two gas rings on for 15 minutes. This compares with a concentration of $260 \mathrm{ppb}$ for 30 minutes associated with increased response to allergen inhalation in the study of Strand et al. ${ }^{39}$ Other short term studies have shown similar effects. ${ }^{40}$

It is known that nitric oxide in the outdoor air rapidly disappears due to its reaction with ozone to form $\mathrm{NO}_{2}$. Indoors, however, we found that concentrations of $\mathrm{NO}$ exceeded those of $\mathrm{NO}_{2}$ for at least 2 hours after our experiments on the gas cooker and oven (fig 1 and 2). Farrow et $a l^{41}$ hypothesised that diarrhoea (that was significantly associated with $\mathrm{NO}_{2}$ concentrations) might in fact have been due to exposure to high concentrations of NO. It is even possible that prolonged exposure to NO, by influencing natural production of NO by endothelial cells, could be responsible for some of the cardiac effects associated exposures of people working in a kitchen, as the sampling took place at a fixed place at head 
epidemiologically with $\mathrm{NO}_{2}$; no studies are known to have investigated this hypothesis further.

As well as carbon particles and $\mathrm{NO}_{\mathrm{x}}$, cooking is associated with the generation of fatty particles, which might themselves be a health hazard. ${ }^{31}$ Several studies have shown aerosols from cooking oils to be mutagenic ${ }^{42} 43$ and genotoxic, ${ }^{44}$ possibly contributing to the raised incidence of lung cancer found among Taiwanese and Chinese women, not entirely explicable by exposure to cigarette smoke. ${ }^{45}$ Recently, Ko et $a l^{47}$ published details on cooking conditions and habits of 131 non-smoking incident cases of newly diagnosed lung cancer in women and found that the risk of lung cancer increased with the number of meals cooked each day, with not using a fume extractor, and with waiting until fumes were emitted from the oil before they began cooking. In our study we found generation of UFPs to be higher for gas cooking, probably due to the higher immediate temperature the oil is exposed to.

In summary, cooking in a poorly ventilated kitchen may give rise to potentially toxic concentrations of particles. If gas is used, high concentrations of $\mathrm{NO}_{\mathrm{x}}$ are also generated, which if not adequately extracted could cause real risks to respiratory and possibly cardiac health of exposed people. Further studies of the relations between indoor exposure to $\mathrm{NO}_{x}$ and cardiac events are necessary.

We are grateful to the United Kingdom Department of Health for financial support for this study and to Professor R Maynard for his encouragement. We also thank Professor L Wallace for his useful comments.

1 Pope CA, Dockery DW, Spengler JD, et al. Respiratory health and $\mathrm{PM}_{10}$ pollution. A daily time series analysis. $A m$ Rev Respir Dis 1991;144:668-74.

2 Pope CA, Dockery DW. Acute health effects of $\mathrm{PM}_{10}$ polluPope CA, Dockery DW. Acute health effects of $\mathrm{PM}_{10}$ pollu-
tion on symptomatic and asymptomatic children. Am Rev tion on symptomatic and as

3 Schwartz J, Slater D, Larson TV, et al. Particulate air pollution and hospital emergency room visits for asthma in Seattle. Am Rev Respir Dis 1993;147:826-31.

4 Dockery DW, Pope CA. Acute effects of particulate air pollution. Annu Rev Public Health 1994;15:107-32.

5 Seaton A, MacNee W, Donaldson K, et al. Particulate air pollution and acute health effects. Lancet 1995;345:176-8

6 Ferin J, Oberdörster G, Penney DP, et al. Increased pulmonary toxicity of ultrafine particles? 1 . Particle clearance,
translocation, morphology. F Aerosol Sci 1990;21:381-4.

7 Ferin J, Oberdörster G, Penney DP. Pulmonary retention of ultra-fine and fine particles in rats. Am $\mathcal{F}$ Respir Cell Mol Biol 1992;6:535-42.

8 Warheit DB, Seidel WC, Carakostas MC, et al. Attenuation of perfluoropolymer fume pulmonary toxicity: effects of filof perfluoropolymer fume pulmonary toxicity: effects of filters, com $309-29$.

9 Donaldson K, MacNee W. In: Hester RE, Harrison RM, eds. The mechanism of lung injury caused by $P M_{10}$. Issues in environmental science and technology, No 10. London: Royal Society of Chemistry, 1998:21-32.

10 Pekkanen J, Timonen KL, Ruuskanen J, et al. Effects of ultrafine particles in urban air on peak expiratory flow among children with asthmatic symptoms, Environ Res 1997;74:24-33.

11 Peters A, Wichmann HE, Tuch T, et al. Respiratory effects are associated with the number of ultrafine particles. $A m \mathcal{F}$ Respir Crit Care Med 1997;155:1376-83.

12 Osunsanya T, Prescott G, Seaton A. Acute respiratory effects of particles: mass or number? Occup Environ Med 2000;58:154-9.

13 Tunnicliffe WS, Burge PS, Ayres JG. Effect of domestic concentrations of nitrogen dioxide on airway responses to inhaled allergen in asthmatic patients. Lancet 1994;344: inhaled $1733-6$.

14 Touloumi G, Katsouyanni K, Kmirou D. Short-term effects of ambient oxidant exposure on mortality: a combined analysis within the APHEA project. Am $\mathcal{f}$ Epidemio 1997;146:177-85.
15 Hajat S, Haines A, Goubet SA, et al. Association of air pollution with daily GP consultations for asthma and other lower respiratory conditions in London. Thorax 1999;54: $597-605$

16 Anderson HR, Ponce de Leon A, Bland JM, et al. Air pollution, pollen, and daily admissions for asthma in London 1987-92. Thorax 1998;53:842-8.

17 Peters A, Liu E, Verrier RL. Air pollution and incidence of cardiac arrhythmia. Epidemiology 2000;11:11-17.

18 Ozkaynak H, Xue J, Spengler J, et al. Personal exposure to airborne particulates and metals; results from the particle TEAM study in Riverside, California. $\mathcal{F}$ Expo Anal Environ Epidemiol 1996;6:57-78.

19 Melia RJW, Florey C, Altman D, et al. Association between gas cooking and respiratory disease in children. BMF 1977; ii: $149-52$.

20 Speizer FE, Ferris B, Bishop YM, et al. Respiratory disease rates and pulmonary function in children associated with $\mathrm{NO}_{2}$ exposure. Am Rev Respir Dis 1980;121:3-10.

21 Volkmer RE, Ruffin R, Wigg NR, et al. The prevalence of respiratory symptoms in South Australian pre-school children: II factors associated with indoor air quality. Fournal of Paediatrics and Child Health 1995;31:116-20.

22 Ware JH, Dockery DW, Spiro A, et al. Passive smoking, gas cooking, and respiratory health of children living in six cities. Am Rev Respir Dis 1984;129:366-74.

23 Jarvis D, Chinn S, Luczynska C, et al. Association of respiratory symptoms and lung function in young adults with use of domestic gas appliances. Lancet 1996;347:426-31.

24 Jarvis D, Chinn S, Sterne J, et al. The association of respiratory symptoms and lung function with the use of gas for cooking. Eur Respir f 1998;11:651-8.

25 Garrett MH, Hooper MA, Hooper BM, et al. Respiratory symptoms in children and indoor exposure to nitrogen dioxide and gas stoves. Am $\mathcal{F}$ Respir Crit Care Med 1998;158:891-5.

26 Dick CAJ, Dennekamp M, Howarth S, et al. Stimulation of IL-8 release from epithelial cells by gas cooker $\mathrm{PM}_{10}$ : a pilot study. Occup Environ Med 2001;58:208-10.

27 Dimitroulopoulou C, Ashmore MR, Byrne MA, et al. Modelling of indoor exposure to nitrogen dioxide in the UK. Atmosphere and Environment 2001;35:269-79.

28 Willeke K, Baron PA. Aerosol measurement: principles, techniques, and applications. New York: Van Nostrand Reinhold, 1993.

29 Wallace L. Real-time monitoring of particles, $\mathrm{PAH}$, and CO in an occupied townhouse. Appl Occup Environ Hyg 2000; 15:39-47.

30 Abt E, Suh HH, Allen G, et al. Characterization of indoor particle sources: a study conducted in the metropoliton Boston area. Environ Health Perspect 2000;108:35-44.

31 Siegmann K. Sattler K. Aerosol from hot cooking oil, a possible health hazard. F Aerosol Sci 1996;27(suppl 1):S493-4.

32 Expert Panel on Air Quality Standards. Nitrogen dioxide. London, The Stationery Office, 1996.

33 Berry RW, Brown VM, Coward SKD, et al. Indoor air quality in homes: Parts 1 and 2. Garston, Watford, UK: Building Research Establishment, 1996.

34 Cyrys J, Heinrich J, Richter K, et al. Sources and concentrations of indoor nitrogen dioxide in Hamburg (west Germany) and Erfurt (east Germany). Sci Total Environ 2000;250.51-62.

35 Chao CYH, Law A. A study of personal exposure to nitrogen dioxide using passive samplers. Building and Environment 2000;35:545-53

36 Quackenboss JJ, Spengler JD, Kanarek MS, et al. Personal exposure to nitrogen dioxide: relationship to indoor/ outdoor air quality and activity patterns. Environ Sci Technol 1986;20:775-82.

37 Spengler JD, Schwab M, Ryan PB, et al. Personal exposure to nitrogen dioxide in the Los Angeles basin. F Air Waste Manag Assoc 1994;44:39-47.

38 Levy JI, Lee K, Spengler JD, et al. Impact of residential nitrogen dioxide exposure on personal exposure: an international study. F Air Waste Manag Assoc 1998;48:55360.

39 Strand V, Rak S, Svartengren M, et al. Nitrogen dioxide exposure enhances asthmatic reaction to inhaled allergen in exposure enhances asthmatic reaction to inhaled allergen in $881-7$.

40 Pilotto LS, Douglas RM, Attewell RG, et al. Respiratory effects associated with indoor nitrogen dioxide exposure in children. Int $\mathcal{F}$ Epidemiol 1997;26:788-96.

41 Farrow A, Greenwood R, Preece S, et al. Nitrogen dioxide, the oxides of nitrogen, and infants' health symptoms. Arch Environ Health 1997;52:189-93.

42 Chiang $\mathrm{T}$, Wu P, Ko Y. Identification of carcinogens in cooking oil fumes. Environ Res A 1999;81:18-22.

$43 \mathrm{Li} \mathrm{SG}$, Pan DF, Wang GX. Analysis of polycyclic aromatic hydrocarbons in cooking oil fumes. Arch Environ Health 1994;49:119-22.

44 Wu PF, Chiang TA, Ko YC. Genotoxicity of fumes from heated cooking oils produced in Taiwan. Environ Res 1999; 80:122-6.

45 Ko YC, Lee CH, Chen MJ. Risk factors for primary lung cancer among non-smoking women in Taiwan. Int $\mathcal{F}$ Epidemiol 1997;26:24-31.

46 Gao YT, Blot WJ, Zheng W. Lung cancer among Chinese women. Int 7 Cancer 1987;40:604-9.

47 Ko YC, Cheng LSC, Lee CH, et al. Chinese food cooking and lung cancer in women non-smokers. Am $\mathcal{F}$ Epidemiol 2000;151:140-7. 